\title{
Review: \\ Progress and potential of DNA barcoding for species identification of fish species
}

\author{
AYESHA IMTIAZ ${ }^{1,2}$, SITI AZIZAH MOHD NOR ${ }^{1,3}$, DARLINA MD. NAIM ${ }^{1, \bullet}$ \\ ${ }^{1}$ School of Biological Sciences, Universiti Sains Malaysia (USM), 11800, Penang, Malaysia. Tel. +60-46534056, ”email: darlinamdn@usm.my \\ ${ }^{2}$ Government Degree College for Women 98NB, Punjab Education Department, Higher Education Wing, Sargodha, Pakistan \\ ${ }^{3}$ Centre for Marine and Coastal Studies, Universiti Sains Malaysia, Penang, Malaysia
}

Manuscript received: 22 April 2017. Revision accepted: 1 September 2017.

\begin{abstract}
Imtiaz A, Mohd Nor SA, Md. Naim D. 2017. Review: Progress and potential of DNA barcoding for species identification of fish species. Biodiversitas 18: 1394-1405. DNA barcoding is a molecular technique to identify species by utilizing $600-800$ base pairs genetic primer segments of mitochondrial gene cytochrome oxidase I. DNA barcoding has high potential to identify species into taxa, resolves ambiguousness in species identification, helps in accurate species identification, categorize species for conservation and also communize the information in the form of database system. The main challenge to this technique is regarding the use of barcoding information on 'biological species concept'. The extreme diversity of fish and their economic importance has made this group a major target of DNA barcoding. DNA barcoding can assign the status of known to unknown sample but it also has the ability to detect previously un-sampled species as distinct. In this review, we present an overview of DNA barcoding and introduce current advances and limitation of this promising technique.
\end{abstract}

Keywords: Cytochrome c oxidase I, barcode gap, DNA barcoding, fish diversity, NUMTS

\section{INTRODUCTION}

In modern society, the major environmental crisis is the loss of biodiversity and the decline is variable among different taxa. The issue has been highlighted at various levels. However, attempts to conserve biodiversity remained uncertain because the exact global baseline data is not available and the rate of loss is unknown, particularly in terms of background knowledge (Dirzo and Raven 2003). Although taxonomic history began since 250 years ago, there are still unknown numbers of species remain undiscovered and new species are waiting to be uncovered. Until now, there are only a few estimates about biodiversity have been published. Mora et al. (2011) reported in a study about globally unidentified biodiversity that $86 \%$ terrestrial species need their taxonomic identity whereas in marine biodiversity this number is extremely high (91\% species). The standardized techniques and methods need to be developed for data acquisition of biodiversity in order to cope up the current biodiversity crisis. The importance of biodiversity in other fields of biology, i.e. ecology, evolutionary biology, molecular biology and biotechnology have been increased due to its crucial role in identifying specimens accurately (Simberloff et al. 2013). Being a most promising approach, 'DNA barcoding' is dominant among all identification techniques. Moreover, the advancement in biotechnology and taxonomic crisis helped in the creation of DNA barcoding technique.

DNA barcoding is helping taxonomists in terms of identification, discovery and genetically studying of specimens in order to achieve certain goals, i.e. knowledge about species diversity and level of variation among species. The challenge of DNA barcoding technique is not only trying to correctly identify species but also to make a standardized global reference library based on the identification of target specimen (Kerr et al. 2007). Several researchers recommended utilizing DNA barcoding techniques because it is cost effective, fast and authentic for species conservation ( $\mathrm{Li}$ and Dao 2011). Using barcode data, stakeholders can collect conservation information, researchers can identify species without using the traditional method, taxonomists can resolve ambiguities in classification and policy makers can estimate the levels of conservation thus will depict proper management strategies for a species concerned (Francis et al. 2010).

The purpose of this review is to provide a critical overview of DNA barcoding and at what extent that this technique can realistically contribute to a practical identification of global biodiversity and biodiversity conservation efforts. We first address the scope of DNA barcoding as a standardized identification system, argue about the efficiency of DNA barcoding that depends on the use of integrative taxonomy, and assess the potential role of barcoding especially in the area of fisheries and most significantly in the conservation of known biodiversity.

\section{OVERVIEW OF DNA BARCODING PROJECT}

Short DNA sequences had been used for microbial species discrimination in early 80's (Kwok et al. 1984) and later had been tested on a variety of organisms (Chaves et 
al. 2012). In 2003 it was the first time when Hebert et al. (2003) proposed that mitochondrial DNA cytochrome oxidase subunit I (COI) gene has the capability to serve as a barcode of all animals. DNA barcoding serves as a golden bullet for not only species identification, but also it delimits species boundaries. With this revolution in taxonomy, the Barcode of Life (BOL) project was launched to develop a globally accepted barcode system that is based on standard sequence of mitochondrial cytochrome oxidase I (COI) gene to identify eukaryotes and also enlist global biodiversity at a platform. Later in 2004, the Consortium for the Barcode of Life (CBOL) inaugurated this project. The aim of CBOL was to develop a standard protocol of DNA extraction, PCR and sequencing techniques, which aid the formation of a global DNA library. CBOL entered a new phase with the launch of iBOL (International Barcode of Life, http: //www.ibol.org) consisting of the collaboration of 26 countries that aimed to enlist eukaryotic biodiversity. In the initial few years, the iBOL concentrated mainly on a collection of maximum barcode sequences in a barcode library from all over the world to achieve the target of five million species barcodes. The iBOL also developed protocols, bioinformatics software with a huge data library. The purpose of these projects was to focus each animal group for making DNA barcode libraries. Some important project includes Fish-BOL (Fish barcode of life), Health BOL, Lepidoptera BOL, MarBOL (Marine Barcode of life), MBI (Mosquito Barcode of life), Mammalia Barcode of life campaign, Coral Reef Barcode of life, BeeBOL (Bee barcode of life) and CBOL fungal working group. Many countries have already collaborated to enlist their regional biodiversity and launched their own country's sub-projects i.e., Norway (NorBOL), Mexico (MexBOL), Japan (JBOLI) and Europe (ECBOL). Many regional based small projects on DNA barcoding are also under completion to identify unique biodiversity in small areas such as The Área de Conservación Guanacaste, a World Heritage Site in Costa Rica, which also combines barcoding project on insects (Hajibabaei et al. 2006; Janzen et al. 2009). Another example is the Moorea Bio Code Project, a comprehensive inventory of Moorea Island in French Polynesia that incorporates DNA barcoding (Check 2006). The DNA barcode from all projects was submitted to a database made by Canadian Center for DNA Barcoding (CCDB). BOLD is freely available to any researcher through the web page ( http://www.boldsystems.og/index.php/Login/page?destinati on=MAS_Management_User Console).

DNA barcoding is the beginning of a revolution in species identification, in which can be accessed from the DNA libraries data record. BOLD provides information for basic identification by matching with the closely related individual, quality of sequences, as well as the quality of a core analysis by generating graphs of inter and intraspecific genetic distances, barcode gap, haplotype distributions and tree reconstructions (Ratnasingham and Hebert 2007).

\section{AUTHENTICITY OF DNA BARCODING}

DNA barcoding uses small regions of mitochondrial DNA that work as a barcode to amplify a gene. DNA sequencing and matching of unidentified sequence with the closely related individual in BOLD or NCBI libraries can be conducted within hours, so the response time depends greatly on available infrastructures, such as reference sequence or voucher specimen in NCBI and BOLD libraries. DNA barcoding is now well established; leads typically to accurate results and the DNA sequencing costs are low and constantly dropping. A major benefit of DNAbased analytical procedures is that they can be applied throughout the food supply chain, from whole specimens to trace samples (scales and fins), to highly processed and cooked fish products (Cawthorn et al. 2012). In addition, DNA analysis is use readily on not only fresh fish samples but also preserved historical material (bones and/or scales from museums).

\section{The validity of the COI gene: For all or some species?}

Mitochondrial Cytochrome c Oxidase subunit I (COI) is a mitochondrial DNA gene that codes a protein, which helps in cellular respiration. A 650 base pairs region of mitochondrial COI is considered as a universal barcode for animals because of its comparatively fast mutation rate over a relatively short time scale, has a high number of exons, high availability throughout cells and maternal inheritance (Steinke et al. 2009b). Due to these characteristic, the mitochondrial COI gene is a perfect universal barcode for species- level identification in sponges (Vargas et al. 2012), Platyhelminthes (Van Steenkiste et al. 2015), annelids (Achurra et al. 2013), molluscs (Layton et al. 2014), insects (Park et al. 2011), oysters (Zainal Abidin et al. 2016), echinoderms (Hemery et al. 2012), fish (Basheer et al. 2016), amphibians (Xia et al. 2012), reptiles (Hawlitschek et al. 2013), birds (Saitoh et al. 2015) and mammals (Alfonsi et al. 2013) (Table 1).

Although COI gene is considered as a universal barcode in animals, its potency is challenging in some protists, fungi, and plants (Schoch et al. 2012). In fungi, internal transcribed spacer (ITS) gene is more successful than COI gene to discriminate closely related taxa (Dentinger et al. 2010). Only a few published data are available on the successful of COI gene as a barcode in algae (Clarkston and Saunders 2010; Macaya and Zuccarello 2010). It has been reported that a universal plastid amplicon (UPA) works well as a barcode in algae instead of COI (Sherwood 2007). Furthermore, Saunder and Kucera (2010) reported that major advantage of UPA is its universality because this primer pair can reliably recover sequences from many groups of algae including green, red and brown marine macroalgae, diatoms, and also cyanobacteria (Sherwood and Presting 2007).

By the same token, the COI gene cannot be used as barcodes for some species of protists, which does not have mitochondrial DNA like anaerobic protists (Gómez 2014). Due to the ineffectiveness of the COI gene as a universal primer for protists, ribosomal subunits has been proposed to carry out that function well (Pawlowski et al. 2012). Moreover, low substitution rate, the high tendency of hybridization and polyploidy among closely related species of plants are the few factors that result in the failure of using mitochondrial COI gene as a universal primer in 
plants (Kiewnick et al. 2014). Therefore, the combination of two alternative sequences in chloroplast DNA namely ribulose bisphosphate carboxylase and maturase $\mathrm{K}$ has been proposed as a standard barcode for the plant (Group et al. 2009).

\section{DNA barcoding as an efficient tool for species identification}

DNA barcoding is an advanced and efficient method for species identification. Various set of primers of mitochondrial gene for barcoding are available in published data. Researchers can also design primers by using different software, for example, PRiFi (Fredslund et al. 2005), BARCRAWL BARTAB (Frank 2009) and PrimerBlast (Ye et al. 2012). A good primer of a specific gene is basic key of success in PCR protocols. The translated sequences of unidentified samples after sequencing can be easily aligned by using various downloadable software or even online, such as ExPASy which is Sib information resource portal (Artimo et al. 2012) (www.expasy.org/genomics/sequence_alignment), MEGA version 6.06 (Tamura et al. 2013) (www.megasoftware.net) and MAFFT version 7 (Katoh and Sandley 2013) (http://mafft.cbrc.jp/alignment/software).

The identification of a voucher specimen that is barcoded can also be confirmed by traditional taxonomy. However, traditional taxonomy fails to discriminate some species due to several conditions, for example, species that having various external body colorations especially when specimens are not fresh (Sriwattanarothai et al. 2010), museum preserved species (Hebert et al. 2013) and samples showing phenotypic plasticity (Weigand et al. 2011). Unlike the traditional taxonomy, DNA barcoding gives information on cryptic (Lim et al. 2016; Thiriet et al. 2016) and sibling species (Blanco-Bercial et al. 2014; Shao'eSun et al. 2016). This identification technique fully supports the improvement of animal classification as well as helps to sort out any ambiguity at the species level. However, DNA barcoding with the support of traditional taxonomy has the capability to identify species complexes within populations (Martínez-Aquino et al. 2009; Iwatsuki et al. 2015).

Table 1. Universality of mitochondrial COI gene as barcode in various groups of animals

\begin{tabular}{|c|c|c|c|c|c|}
\hline Taxa name & No of taxa & $\begin{array}{c}\% \\
\text { identified }\end{array}$ & $\begin{array}{l}\text { Sampling } \\
\text { location }\end{array}$ & Mitochondrial COI Primers & References \\
\hline Fish & 203 species & $>98 \%$ & Canada & FishF1, FishR1 & Hebert et al. (2003) \\
\hline Birds & 643 species & $>98 \%$ & North America & $\begin{array}{l}\text { BirdF1, BirdR1, FalcoFA, Vertebrate } \\
\text { R1, BirdR2 }\end{array}$ & Hebert et al. (2004) \\
\hline Neo tropical bats & 87 species & $>97 \%$ & Guyana & $\begin{array}{l}\text { CVF1di, CVR1di, CVF1LFT1, } \\
\text { CVR1LRt1, LepF1t1, LepR1t1 }\end{array}$ & Clare et al. (2007) \\
\hline Fish & 94 species & $>98 \%$ & Canada & 16S, COI1, COI2, COI 3, M13 & Ivanova et al. (2007) \\
\hline Chondrichthyes & 200 species & $>98 \%$ & $\begin{array}{l}\text { North Atlantic } \\
\text { and } \\
\text { Australasia }\end{array}$ & FishF1, FishR1, HCO2198 & Ward et al. (2008) \\
\hline Ornamental fish & 201 species & $>98 \%$ & Canada & FishF1, FishR1 & Steinke et al. (2009a) \\
\hline Birds & 756 species & $>98 \%$ & Iran & $\begin{array}{l}\text { BirdF1, BirdR1, BirdR2, 16SAL, } \\
\text { 16SBH }\end{array}$ & Aliabadian et al. (2009) \\
\hline Fish & 115 species & $>98 \%$ & India & FishF1, FishR1 & Lakra et al. (2011) \\
\hline Marine fish & 158 species & $>98 \%$ & Japan & FishF1, FishR1 & $\begin{array}{l}\text { Zhang and Hanner } \\
\text { (2011) }\end{array}$ \\
\hline Freshwater fish & 105 species & $100 \%$ & Brazil & $\begin{array}{l}\text { CFishF1t1, CFishR1t1, VF1LFt1, } \\
\text { VR1LRt1 }\end{array}$ & $\begin{array}{l}\text { de Carvalho et al. } \\
\text { (2011) }\end{array}$ \\
\hline $\begin{array}{l}\text { Oriental Black } \\
\text { (Diptera) }\end{array}$ & 41 species & $>96 \%$ & Thailand & LCO1490, HCO2198 & $\begin{array}{l}\text { Pramual and Adler } \\
\text { (2014) }\end{array}$ \\
\hline Amphibians & 82 species & $100 \%$ & China & $\begin{array}{l}\text { dgLCO, LCO1490, Chmf4, COI-C02, } \\
\text { COI-C01, LEPF1, dgHCO, HCO2198, } \\
\text { Chmr4, COI-C04, COI-C03, LEP-R1 }\end{array}$ & Che et al. (2012) \\
\hline Reptiles & $>250$ species & $100 \%$ & Madagascar & RepCOIF, RepCOIR & Nagy et al. (2012) \\
\hline Reptiles & 27 species & $100 \%$ & $\begin{array}{l}\text { Comoros } \\
\text { Archipelago }\end{array}$ & $\mathrm{LCO}, \mathrm{HCO}$ & $\begin{array}{l}\text { Hawlitschek et al. } \\
\text { (2013) }\end{array}$ \\
\hline Amphibians & 251 species & $>94 \%$ & Madagascar & $\operatorname{dgLCO} 1490, \operatorname{dgHCO} 2198$ & Perl et al. (2014) \\
\hline Hymenoptera & 4118 species & $>90 \%$ & Europe & $\begin{array}{l}\text { As used by Ivanova et al. } 2006 \text { and } \\
\text { deWaard et al. } 2008\end{array}$ & Schmidt et al. (2015) \\
\hline Cyprinid & 35 species & $100 \%$ & China & FishF1, FishR1, FishF2, FishR2 & Shen et al. (2016) \\
\hline
\end{tabular}




\section{STANDARD LABORATORY PROCEDURE (SLP) OF DNA BARCODING}

Barcoding is a worldwide project where hundreds of laboratories have been involved in enlisting the global biodiversity. Accordingly, new methodologies of DNA extraction and Polymerase Chain Reaction (PCR) (Handy et al. 2016) has been increasingly developed in parallel with the development of barcoding primers. To standardize the handling of DNA barcoding samples, BOLD has already made standard laboratory procedure (SLP) (Keele et al. 2013). In SLP (Fig 1) preferably fresh few millimetersized tissue is placed in $1.5 \mathrm{~mL}$ Eppendorf tube. Fish Barcoding Method (Handy et al. 2016) which is also available online at BOLD website (http: //www.dnabarcoding101.org/files/using-dna-barcodes.pdf) does DNA extraction. Species-specific primer or universal DNA barcoding primers (based on animals group i.e. invertebrate, plant, mammal, etc.) was used for PCR amplification. Positive control band ( a sample that is known to give a positive band for the chosen primers) is included in PCR as a positive control. A negative control ( a mixture containing no DNA template) is also loaded in PCR mixture to ensure that the master mix does not contain contaminating DNA. The PCR amplification is analyzed by loading PCR-amplified products on an agarose gel electrophoresis with a standard marker (DNA of known base pair size), such as 1-kilo base pairs (kbp) DNA ladder (i.e. First Base Laboratories, Sdn Bhd). If a bright band is present at the expected size, the PCR product will be purified. There were several purification kits are available in a market such as Mega quick spin of Intron Biotechnology Inc. After confirming a quality and quantity of the purified DNA, the PCR-amplified products were sent to a laboratory for sequencing.

Sequencing results can be analyzed by using National Centre of Biotechnology Information (NCBI) website (https: //www.ncbi.nlm.nih.gov) or BOLD website to determine the maximum identity of an organism with template sequences. BOLD compares unknown sequences with most closely resembling sequences available in the database. This database gives output in the form of resemblance percentage. The standard laboratory procedure is universally approved procedure but of course, for different organism modifications are required in order to obtain the best quality results. The DNA barcoding procedures totally fail if there is no barcode library to register barcoded samples (Ekrem et al. 2007). To develop barcode record, researchers required a species name, voucher specimen data (i.e. locality, date, repository of the specimen, photographs), a sequence data, PCR primers and trace files (sequencer's original outputs). It is estimated that sequencing can take place in less than $90 \mathrm{~min}$ at the cost of $\$ 2-5$ per species, compared to several months of field work and a cost of at least $\$ 100$ per specimen with morphological analyses (Stoeckle and Hebert 2008).

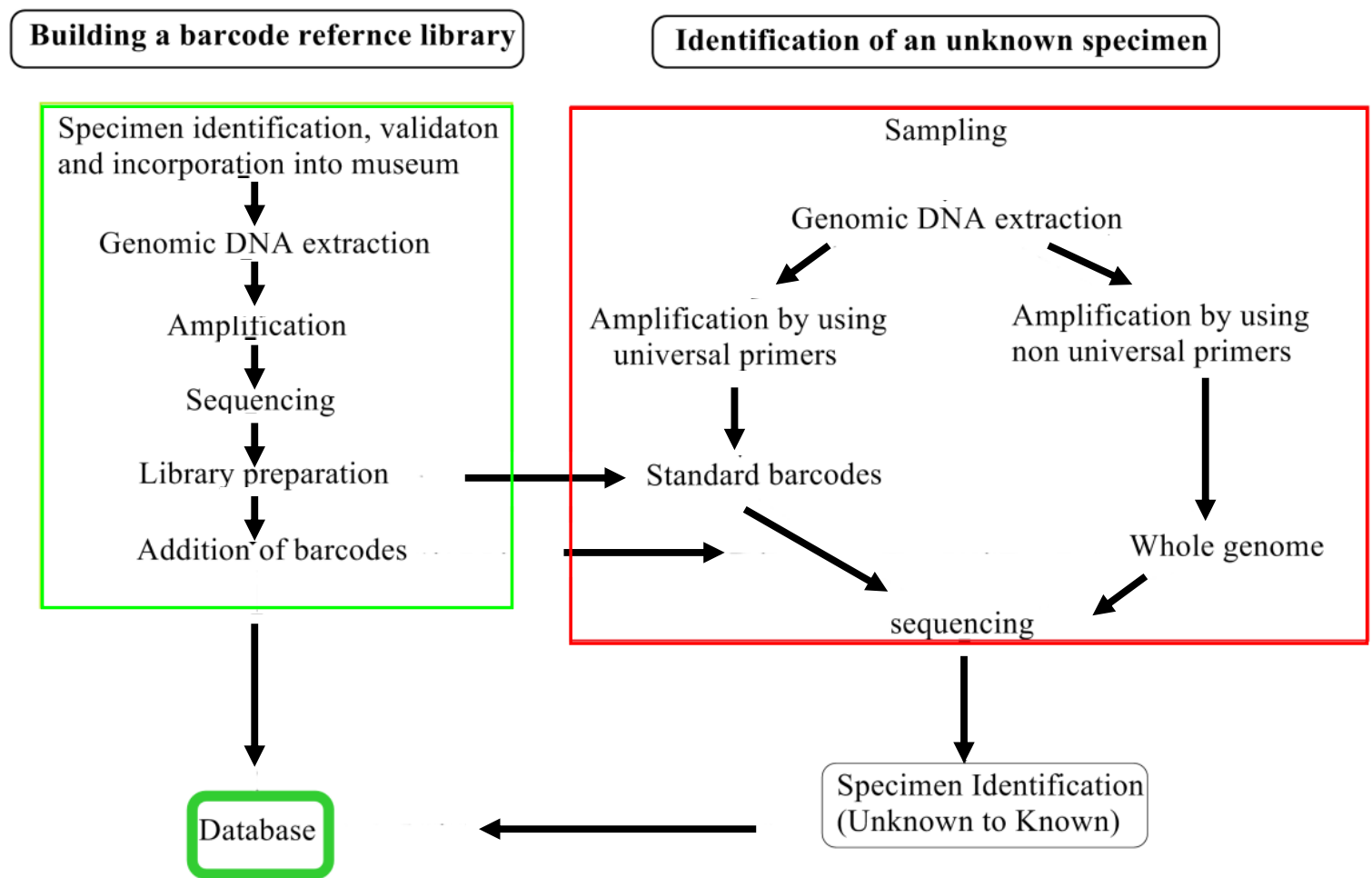

Figure 1. Overview of experimental procedures implemented for barcode libraries 


\section{USE OF LATEST TECHNIQUES IN DNA BARCODING}

\section{Real Time PCR}

The real time PCR is the latest approach in DNA barcoding methods that is used to monitor the progress of PCR reaction in real time (Dias et al. 2016). At the same time, relatively small amount of PCR products cDNA or RNA can be quantified. One can start the PCR even with very small amount of nucleic acid and can quantify the end product quite accurately. Real time PCR technique is basically designed to maximize the amplification of barcode genes even in the presence of low-quality DNA (Doi et al. 2015). For this purpose a reporter molecule is used in PCR that binds to double stranded DNA that increases in number as PCR proceeds and produces fluorescence. The reporter molecules can be in the form of dye (i.e. SYBR Green) or sequence specific probes (Molecular Bacons or TaqMan Probes). The real time PCR is highly sensitive, easy to perform and cost effective, as no post PCR processing is needed that saves time and resources. Real time PCR is also called real time RT PCR that is used to convert DNA into RNA by an additional cycle of reverse transcription. Shokralla et al. (2015) used real time PCR based DNA barcode method as minibarcode system consisting 127-314 base pair fragments of COI gene to identify all types of fish species used in fish products AND successfully identified $93.2 \%$ of samples upto species level. Feng et al. (2017) also recently identified four commercially important species of salmon and trout using real time PCR barcoding technique.

\section{Microarrays}

With the rise of next generation sequencing technologies and non-suitability of COI gene for design of oligonucleotide probes, it was believed that microarray technology is outdated. But developments in microarray technology (Microarray chips, mid-infrared chemical imaging) have refined the barcoding approach (Kochzius et al. 2010). Microarray chips are simple and can efficiently target specific group of species in a single assay. Midinfrared chemical imaging (MICI) uses nanogold-silver augmented hybridized spots in microarrays and detects reflected substrate. These advanced methods of DNA barcoding have been applied in unknown species identification, point mutations, biodiversity assessment and food security (Trivedi et al. 2016). Handy et al. (2014) identified reported misidentification of seven catfish species in USA seafood market by using DNA microarrays with newly developed mid-infrared imaging detection method.

\section{APPLICATIONS OF DNA BARCODING}

With pits and falls of thirteen-year history, DNA barcoding project successfully not only identified a huge number of taxon but also addressed population and conservation issues in biodiversity. The unique features of
DNA barcoding such as species identification, cryptic species and partial phylogenetic assessment is benefits to whole animal kingdom especially both basic and applied fisheries. Species identification methods using molecular data can help elucidate the relationships of morphologically variable individuals of the same species and individual's similarity in different developmental stages. In addition, in the features of typical non-barcode markers, the advantages of DNA barcoding include primer universality, the availability of information on a wide range of taxonomic groups, and its association with taxonomy.

\section{DNA barcoding and species identification}

Genetic identification of biodiversity is the necessity of time due to the presence of phenotypic similarities among neighboring species. Some organisms especially fish shows phenotypic plasticity with a change in its environment (Hutchings et al. 2007). DNA barcoding has the capability to identify not only in adult organisms but also at their early developmental stages. For example, Ko et al. (2013) used DNA barcoding technique to successfully identified 100 specimens of fish larvae with a success rate of $>65$ percent at the species level. However, with an increase in taxonomic level the identity rate also increased up to $>85$ Percent. Likewise, Naim et al. (2012) used COI gene to successfully identified approximately 60 individuals of mud crab into four species. Most recently, COI gene has been used to identify Ivory shell (Chiu et al. 2015), Atlantic goliath groupers (Damasceno et al. 2016) and yellowfin tuna (Higashi et al. 2016).

\section{DNA barcoding and species delimiting boundaries}

A great challenge associated with barcodes is to define species boundaries concepts. The literature on DNA barcoding studies suggests a different threshold approach in different taxa, as $2 \%$ difference in the DNA barcode of mammals implies that the samples are from different species (Cai et al. 2015). This value was considered as a divergence threshold and a standard cutoff value for species delimitation in fishes (Mabragaña et al. 2011). However, Ward et al. (2008) mentioned that $3 \%$ and $1 \%$ is the ideal threshold value for fish and birds respectively. These limitation values are based on the distribution of intra and inter-specific K2P genetic distance values in the approximately 172,000 species that have been barcoded (http: //www.boldsystems.org). It is important to set species delineation boundaries because, in homogenous populations, species identification is problematic. DNA barcoding can interpret a unique taxon as a separate species by recording intraspecific divergence which should be lower than interspecific threshold values.

\section{DNA barcoding as a forensic tool}

DNA samples can be used to check drug authenticity in forensic sciences (Carvalho et al. 2015). Forensically Informative Nucleotide Sequencing (FINS) was one of the earliest species diagnostic techniques for fish (Bartlett and Davidson 1992). In FINS the identity of an unidentified specimen is confirmed by comparing amplified sequence of 
a mitochondrial COI gene fragment taken from the unknown sample to reference sequences in database library of known species. Such interrogative sequencing methodology used different types of genetic markers to identify a variety of meats (Pappalardo and Ferrito 2015). Barcoding provides a fast and reliable method to identify exotic species in a branch of biosecurity: one such example is the identification of the invasive North American bullfrog (Rana catesbeiana) found in water samples from ponds in France by using short mitochondrial fragments (Ficetola et al. 2008). Likewise, the Brazilian Forensic Government Programme reported that there is approximately 24 percent of seafood products has been mislabeled (Carvalho et al. 2015). Under those circumstances, biomedical research highlighted new aspects of DNA barcoding technique such as nextgeneration DNA sequencing, shotgun sequencing, transcriptomes and interactomes (Shendure and Ji 2008). All these techniques help in saving time and speeding up the process of collecting data that previously required a very extended period. DNA barcoding is not too difficult to handle as nonspecialized persons can participate in barcoding campaign by helping in samples collection from various geographical locations and uploading the pictures and other information on database system such as BOLD (http: //www.barcodinglife.org) for further taxonomic interpretation. This information will be used for forensic or biosecurity purposes as described above, henceforth, will encourage local participation in these matters. Such local involvement in barcoding project can lessen the field work of morphological taxonomists.

\section{DNA barcoding and cryptic species}

Fishes show significantly more divergence for COI gene at each hierarchical taxonomic level (Ward 2009). Barcodes have also complimented morphological studies in cases where taxa were easily misidentified due to the existence of cryptic species (Ward et al. 2008). If a sample from an unidentified specimen shows zero divergence from a previously identified specimen, or differs from it by only one or two base pairs, the probability is that it is the same species due to high similarity with the already identified specimen $(>95 \%)$. If on the other hand, the unknown specimen is more than 2 percent divergent from the known specimen, it is very likely (probability greater than 95\%) to be a different species. Khedkar et al. (2014) reported the possibility of sibling species of Labeo dyocheilus by analyzing inter and intraspecific divergence values. Hubert et al. (2012) also revealed cryptic fish diversity in coral reefs of Indo-Malay Philippines Archipelago. Hamaguchi et al. (2017) reported about cryptic diversity in flat oysters distributed in Japan.

\section{DNA barcoding and population diversity}

Mitochondrial DNA markers are not diploid because they are inherited from a single parent (maternal inheritance) so they are equally good for targeting population level studies (Avise 2004). Although the cytochrome oxidase I (COI) gene information from DNA barcoding is not sufficient to investigate population-level questions (Bazin et al. 2006), yet still it can be used to partially interpret the distribution of genomic diversity within taxa. Barcodes can give the status of species to an unknown specimen because they also consist information of genetic models (coalescent-model) based on population genetics (Abdo and Golding 2007). The COI gene provides information about genetic variation within a population of a single species and this information can help to deduce the phenomenon of migration as well as genetic drift in fish populations (Mohammad Geba et al. 2016). To demonstrate, Boonkusol et al. (2016) used mitochondrial COI gene sequences to access the genetic variability in snakehead fish of Thailand and deduced that genetic variation in the central river basin is due to fish dispersal by the flood. In the same fashion, the use of a combination of mitochondrial (COI) and nuclear genes (recombination activating gene-I (Rag I) and from nuclear alpha tropomyosin 'intron $V^{\prime}$ ') can fully address the question of population structure as done by Eytan and Helburg (2010) in Caribbean reef fish.

\section{DNA barcoding and phylogenetic reconstruction}

In barcoding, the information from an assemblage of species is in the form of genetic sequences, which is uploaded in a barcode library. However, the gene lengths from barcoding data are not sufficient to construct a deeper phylogenetic tree in resolving evolutionary relationship of organisms. Although the barcoding sequences have been used to construct Neighbour-Joining (NJ) tree, this barcode-based tree cannot be alternates of the phylogenetic tree. We strongly emphasize on the statement that DNA barcoding data can provide partial information about the phylogeny of species and can draw an outline for phylogeny that should be deeply analyzed by nuclear genes data. Faith and Williams (2005) argued that the most significant contribution of DNA barcoding to conservation efforts is its role in improving and speeding up phylogenetic diversity assessments. Lakra et al. (2011) successfully identified 115 marine fish species that clustered into 79 genera when NJ tree was constructed to see the phylogenetic relationship among collected samples. Ardura et al. (2010) identified 21 Amazonian species, with $100 \%$ bootstrap support was obtained at a specific level in the reconstructed NJ phylogenetic tree.

\section{DNA barcoding and food safety}

The global fish market is facing challenges of seafood authenticity and food safety, although identification keys and molecular approaches (DNA barcoding) have limitations in the identification of species. The market frauds regarding substitution of high priced fish with lowpriced fish in fish products is very common. Wong and Hanner (2008) used barcoding technique in North American seafood to check barcoding aspects of traceability and their specimen data matched of $>97$ percent similarity with barcode library sequences. Twenty-five percent of the samples were potentially mislabeled, demonstrating that DNA barcodes are a powerful tool for identification of seafood to the species level. Likewise, Smith et al. (2008) detected ten families from smoked fish 
products were mislabeled. Furthermore, Yan et al. (2016) identified Alepes apercna, which had surprisingly been labeled as Rastrelliger brachysoma by using COI gene in imported seafood products. Mislabeling in the fish market for economic benefits has become challenging. For this reason, the Food and Drug Administration Department in the United States has adopted DNA barcoding technique to reduce market frauds (Naaum and Hanner 2015).

\section{DNA barcoding and biodiversity conservation}

One of the main goals of DNA barcoding is a utilization of genetic data to boost conservation strategies, and indeed molecular tools were used in conservation biology at different levels of analysis (DeSalle and Amato 2004). Rapid biodiversity assessment is a research priority as species extinction/extirpation rate is high, and barcoding is contributing to biodiversity conservation in facilitating biodiversity assessment cheaply and quickly where financial resources are limited (Krishnamurthy and Francis 2012). The majority of described biodiversity is in developing countries, where resources for comprehensive biodiversity assessments are lacking. For conservation biology, genetic tools can aid in research as diverse as finescale management of coral reefs (Neigel et al. 2007) and regional management of fisheries (Swartz et al. 2008). DNA barcoding contributes to conservation policy in two important ways; 1) by speeding up local biodiversity assessments to prioritize conservation areas or evaluate the success of conservation actions, and 2) by providing information about evolutionary histories and phylogenetic diversity (Rubinoff 2006). Hubert et al. (2012) barcoded 2,276 specimens into 668 coral reef fish species and provided data to biodiversity conservationists for making conservation strategies as his findings remarkably suggested most of the coral reef diversity is accumulated in Indo-Malayan Archipelago. There have been several notable conservation successes using barcoding. For example, the rapid classification of $99 \%$ of 210 chondrichthyan species from 36 families from Australia (Ward et al. 2008) and the identification of larval and juvenile organisms for which morphological data is nonexistent (Neigel et al. 2007), all of which have accelerated conservation priorities and policy response.

Barcoding prosecutes illegal trading of endangered species, even after organisms have been processed. For example, the illegal shark-fin trade is a significant threat to biodiversity in many coastal African countries. The barcoding can identify different varieties of shark, including those that were critically endangered and protected under international legislation (Swartz et al. 2008). Therefore, DNA barcoding in conjunction with a reference database potentially plays a key role in environmental law enforcement and conservation of species that are already studied (Williams et al. 2013).

\section{LIMITATIONS IN DNA BARCODING}

DNA barcoding has attracted significant attention in systematic studies. Yet, the project is controversial because many systematists feel that the conceptual foundation of DNA barcoding remains weak (Waterton et al. 2013). Here are few limitations of DNA barcoding that have been addressed in several types of research.

\section{Barcode gap}

The "barcode gap" refers to the differences between mean intra and interspecific genetic sequence variability of COI sequences within the same genus of animals (Meyer and Paulay 2005) (Fig 2). Large barcoding gaps are routinely used to predict DNA barcoding success for the taxon under study (Clare et al. 2007; Freshwater et al. 2010; Keskln and Atar 2013). The overlapping of genetic divergence values within and between species recorded in histograms shows that there is no gap between inter and intraspecific divergences in samples species (Mayer and Paulay 2005). In this regard, the inter-generic variation and overlapping of differences within and between species distances are ruled (Virgilio et al. 2010). We support the statement of Collins and Cruickshan (2013) that barcoding gaps are currently incorrectly computed and that the values reported in the barcoding literature are misleading. Various authors have pointed out that the use of smallest interspecific distances would be more appropriate (Cognato 2006; Roe and Sperling 2007).

Proper interspecific distances measurements are important for distance-based identification techniques. DNA barcodes with unusually large distances to conspecific sequences are often used to predict the possible existence of cryptic species (Clare et al. 2007). One cannot address the new species by considering barcoding gap only but the cryptic species can be predicted by using smallest intraspecific value (Will and Rubinoff 2004).

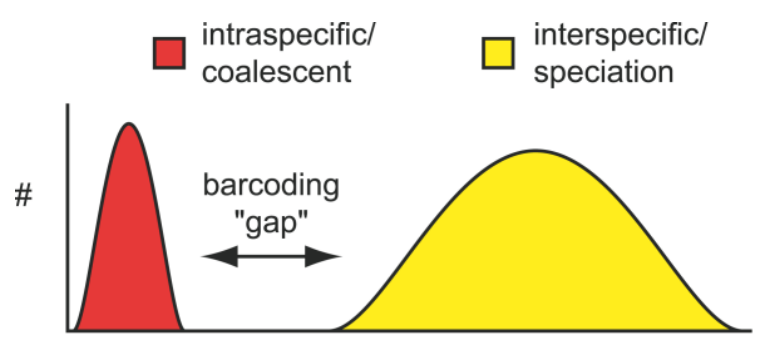

A.

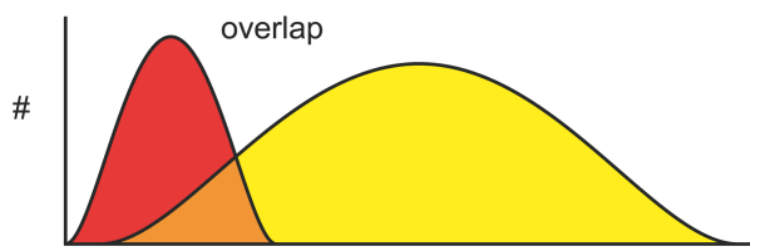

B. genetic distance

Figure 2. Barcode gap (Mayer and Paulay 2005). If there is no overlap between intraspecific and interspecific values as in A, it means the unknown sample has low threshed hold value all species are in their discrete distribution boundaries but if overlap is great as in B it means there are closely related taxa present and making this method problematic 


\section{Barcoding and phylogeny misinterpretation}

Neighbor-Joining tree formation is easy to compute and is a part of standardized analytical procedure as used in various barcoding studies because NJ trees are fully resolved tree that is based on genetic distance matrix of similarity in sequences to create a clustering of taxon in the form of phenogram (Casiraghi et al. 2010). However, several authors have documented that phylogenetic approach to DNA barcoding is inappropriate (Goldstein and De Salle 2011). The NJ tree does not use cladistics sense as an identification system. NJ tree based identification can interpret wrong results about the identification of paraphyletic speciation and incomplete hierarchy (Lowenstein et al. 2010). Few species concepts require reciprocal monophyletic origin (Meier 2008) (Fig 3 ), and in any case, monophyly of mtDNA lineages can be an unrealistic scenario in many closely related groups (Zhang et al. 2012). It is important to note that a quantification of monophyly still remains a useful description of the data, and should be used but in conjunction with other methods. Problems mostly occur when NJ trees are the only analytical method presented (Little and Stevenson 2007). However, for the purpose of graphically summarizing the data, NJ trees can be considered appropriate.

For species identification, we suggest the mitochondrial plus nuclear gene combination with character based diagnostic methods should be used. Bayesian coalescent methods also promise statistical advantages, but may be too computationally inefficient in their current incarnations (Zhang et al. 2012).

\section{NUMTS (Nuclear Mitochondrial Pseudo-genes)}

Nuclear Mitochondrial Pseudo-genes (NUMTS ) are non-active non-coding parts of mitochondrial DNA present in the nucleus of most eukaryotic organisms and can be easily amplified along with mitochondrial DNA even by using conserved universal primers (Song et al. 2008). The presence of co-amplification of NUMTS along with mitochondrial genes is problematic because DNA barcoding analysis can incorrectly overestimate the number of unique species. DNA barcoding is rapid and inexpensive technique of tagging species. However, the presence of NUMTS in COI amplified sequences can make DNA barcoding ambiguous (Buhay 2009). There are several techniques that can be used to control NUMTS such as (i) the use of muscle tissue as a source of DNA due to the presence of high concentration of mitochondrial DNA in those areas and (ii) amplification of longer fragments (750 bp) because barcode sequence is longer than NUMTS sequence (Pereira and Baker 2004). NUMTS is not only a major limitation of DNA barcoding, but also has significant taxonomic implications. Moulton et al. (2010) tried to identify Orthoptera species by using COI gene but the presence of NUMTS led to overestimation and misidentification of species. With attention to this matter, Song et al. (2008) suggested RT-PCR, long PCR, use of markers other than $\mathrm{COI}$ and choice of the mitochondrial rich region for extraction of DNA to avoid NUMTS. Similarly, BOLD also provides an opportunity to detect and delete NUMTS by analyzing sequences with Markov model during analysis.

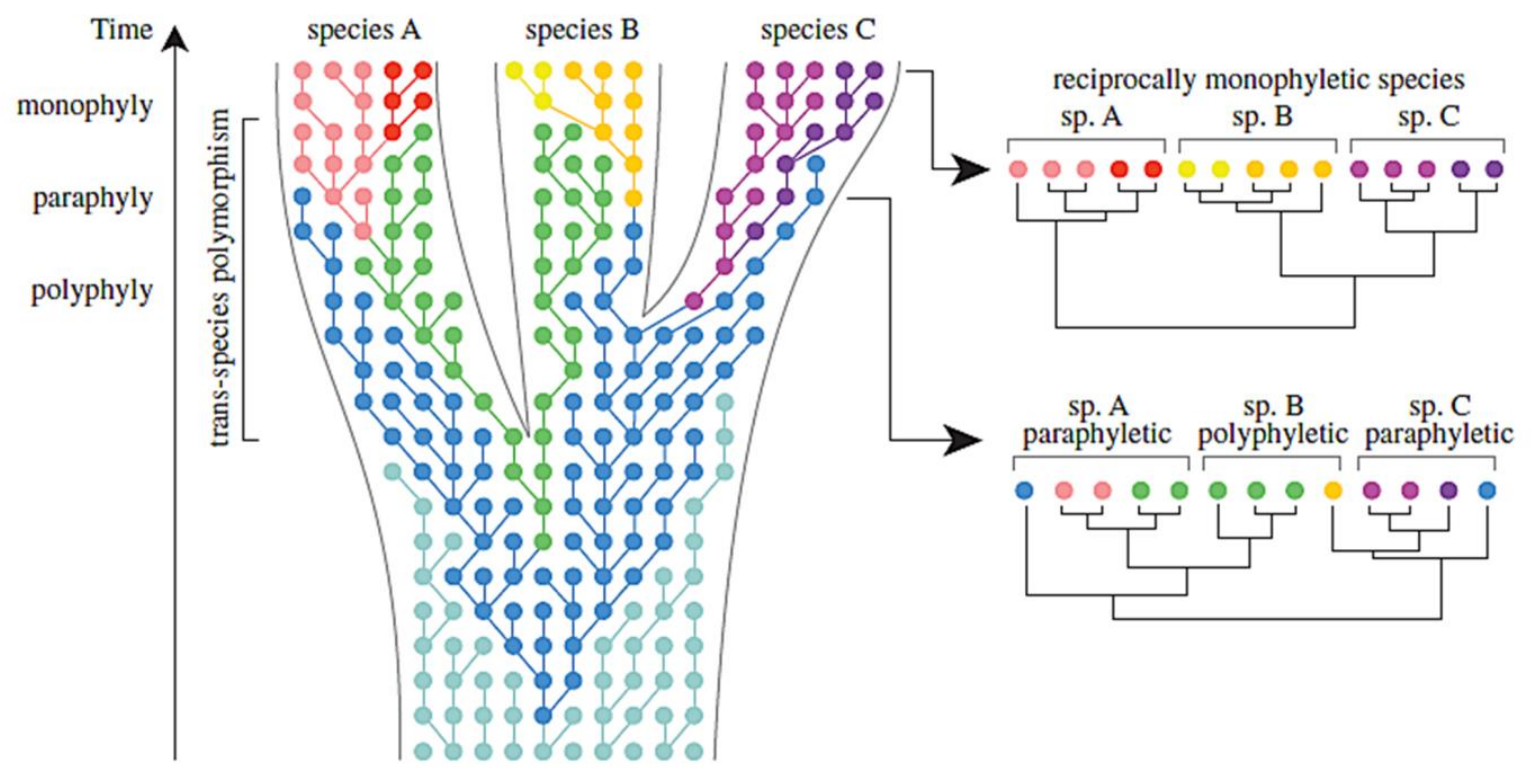

Figure 3. Differences among various types of phylogeny (Leliaert et al. 2014) 


\section{DISCUSSION}

Although DNA barcoding is useful in classifying taxa, it is perhaps premature to suggest that DNA barcoding can offer a replacement for assessment of biodiversity and traditional taxonomy. Instead, we consider barcoding as an additional tool that links genetic data into existing studies. DNA barcodes have been particularly helpful in identifying cryptic diversity within species, especially when it is used in conjunction with other taxonomic methods such as morphology and ecology. DNA barcoding is worth capable of facilitating an integrative approach to species identification but with the involvement of traditional taxonomic studies. The role of DNA barcodes is positive to help in speeding up biodiversity assessments, however, integrative taxonomic methods are still required to address the 'taxonomic impediment' (Wilson 2000). There are three reasons for genetic barcoding should not be used alone for addressing the status of new species to a taxon as formerly described in this review; firstly, no standardized universal distance threshold has been identified for species delimitation, and thresholds vary between different taxa (Yassin et al. 2010). Secondly, discrimination of a closely related species is not an easy task by using a species definition based on only genetic distance data (Meier et al. 2006). Thirdly, for species identification, there is no universal identification technique, as species discovery requires a contribution from other branches of biology (Taylor and Harris 2012). DNA barcoding has the capability to discriminate species but it is quite unjustified to comment that DNA barcoding can replace traditional taxonomy. Additionally, barcoding research has limited success when identifying new species in unstudied groups (Meyer and Paulay 2005). For example, barcoding fails to identify recently isolated populations and reproductively isolated lineages of fish species that have undergone recent speciation (Zou et al. 2016). Even so, DNA barcoding has proved useful in enlisting global biodiversity by enhancing data availability for existing research problems (Rubinoff et al. 2006)

In summary, being taxonomist, we encourage DNA barcoding with a combination of traditional identification methods because it is an objective, quick, easy and replicable method to identify species. DNA barcoding has raised the profile of taxonomic research and contributed a valuable data for conservation of biodiversity. However, decisions for the conservation of a species concerned shall not be based only on DNA barcoding studies. The evidence-based approach to fundamental assessment about species, such as population size, species interaction with the environment and the possible effect of the ecosystem on species should be considered before jumped into conclusion. On the whole, DNA barcoding gives opportunity in various fields of biodiversity in a positive way and we think it will be regrettable to compromise on the efficiency of barcoding due to its presumed limitations.

\section{ACKNOWLEDGEMENTS}

We acknowledge TWAS-USM Penang, Malaysia fellowship. We also say thanks to members of Lab-308 USM Penang, Malaysia for their precious comments to improve this review. This research has been funded by LRGS (MOHE) Malaysia 203/PTS/6727005 and RU Grant (USM) 1001/PBIO/815807 and 304/PBIOLOGI/6311003.

\section{REFERENCES}

Abdo Z, Golding GB. 2007. A step toward barcoding life: a model-based, decision-theoretic method to assign genes to preexisting species groups. Syst Biol 56 (1): 44-56.

Achurra A, Erséus C. 2013. DNA barcoding and species delimitation: The Stylodrilus heringianus case (Annelida: Clitellata: Lumbriculidae). Invertebr Syst 27 (1): 118-128.

Alfonsi E, Méheust E, Fuchs S, Carpentier FG, Quillivic Y, Viricel A, Hassani S, Jung JL. 2013. The use of DNA barcoding to monitor the marine mammal biodiversity along the French Atlantic coast. ZooKeys 365: 5-24. DOI: 10.3897/zookeys.365.5873.

Aliabadian M, Kaboli M, Nijman V, Vences M. 2009. Molecular identification of birds: performance of distance-based DNA barcoding in three genes to delimit parapatric species. PLoS One 4 (1): e4119. DOI: 10.1371/journal.pone.004119.

Ardura A, Linde, AR, Moreira, JC, Garcia-Vazquez E. 2010. DNA barcoding for conservation and management of Amazonian commercial fish. Biol Cons 143 (6): 1438-1443.

Artimo P, Jonnalagedda M, Arnold K, Baratin D, Csardi G, De Castro E, Duvaud S, Flegel V, Fortier A, Gasteiger E, Grosdidier A. 2012. ExPASy: SIB bioinformatics resource portal. Nucleic Acids Res 40 (W1): 597-603.

Avise JC. 2004. Molecular markers, natural history, and evolution, 2nd ed. Sinauer Associates, Sunderland, Massachusetts

Bartlett SE, Davidson WS. 1992. FINS (forensically informative nucleotide sequencing): a procedure for identifying the animal origin of biological specimens. Biotechniques 12 (3): 408-411.

Basheer VS, Chowdhury LM, Mohitha C, Bineesh KK. 2016. Barcoding of Indian marine fishes: for identification and conservation. In: DNA Barcoding in Marine Perspectives. Springer, Berlin.

Bazin E, Glémin S, Galtier N. 2006. Population size does not influence mitochondrial genetic diversity in animals. Science 312 (5773): 570572.

Blanco-Bercial L, Bucklin A. 2016. New view of population genetics of zooplankton: RAD-seq analysis reveals population structure of the North Atlantic planktonic copepod Centropages typicus. Mol Ecol 25 (7): 1566-1580. DOI: $10.1111 / \mathrm{mec} .13581$

Boonkusol D, Tongbai W. 2016. Genetic variation of striped snakehead fish (Channa striata) in River Basin of Central Thailand Inferred from mtDNA COI Gene Sequences Analysis. J Biol Sci 16 (1-2): 3743

Buhay JE. 2009. "COI-like" sequences are becoming problematic in molecular systematic and DNA barcoding studies. J Crustacean Biol 29 (1): 96-110.

Cai Y, Zhang L, Wang Y, Liu Q, Shui Q, Yue B, Zhang J, Li J. 2015. Identification of deer species (Cervidae, Cetartiodactyla) in China using mitochondrial cytochrome c oxidase subunit I (mtDNA COI). Mitochondrial DNA A DNA Mapp Seq Anal. 27 (6): 4240-4243.

Carvalho DC, Palhares RM, Drummond MG, Frigo TB. 2015. DNA Barcoding identification of commercialized seafood in South Brazil: a governmental regulatory forensic program. Food Control 50: 784788.

Casiraghi M, Labra M, Ferri E, Galimberti A, De Mattia F. 2010. DNA barcoding: a six-question tour to improve users' awareness about the method. Brief Bioinform 11(4): 440-453.

Cawthorn DM, Steinman HA, Witthuhn RC. 2012. DNA barcoding reveals a high incidence of fish species misrepresentation and substitution on the South African market. Food Res Intl 46 (1): 30-40.

Chaves PB, Graeff VG, Lion MB, Oliveira LR, Eizirik E. 2012. DNA barcoding meets molecular scatology: short mtDNA sequences for 
standardized species assignment of carnivore non invasive samples. Mol Ecol Resour 12 (1): 18-35.

Che J, Chen HM, Yang JX, JIn J Q, Jiang KE, Yuan ZY, Murphy RW, Zhang YP. 2012. Universal COI primers for DNA barcoding amphibians. Mol Ecol Resour 12 (2): 247-258.

Check E. 2006. Treasure island: pinning down a model ecosystem. Nature 439: 378-379.

Chiu TH, Kuo CW, Lin HC, Huang DS, Wu PL. 2015. Genetic diversity of ivory shell (Babylonia areolata) in Taiwan and identification of species using DNA-based assays. Food Control 48: 108-116.

Clare EL, Lim BK, Engstrom MD, Eger JL, Hebert PD. 2007. DNA barcoding of Neotropical bats: species identification and discovery within Guyana. Mol Ecol Notes 7 (2): 184-190.

Clarkston BE, Saunders GW. 2010. A comparison of two DNA barcode markers for species discrimination in the red algal family Kallymeniaceae (Gigartinales, Florideophyceae), with a description of Euthora timburtonii sp. nov. Botany 88 (2): 119-131.

Cognato AI. 2006. Standard percent DNA sequence difference for insects does not predict species boundaries. J Econ Entomol 99 (4): 1037 1045.

Collins RA, Cruickshank RH. 2013. The seven deadly sins of DNA barcoding. Mol Ecol Resour 13 (6): 969-975

Damasceno JS, Siccha-Ramirez R, Oliveira C, Mendonça FF, Lima AC, Machado LF, Tosta VC, Farro APC, Hostim-Silva M. 2016. Molecular identification of Atlantic goliath grouper Epinephelus itajara (Lichtenstein, 1822) (Perciformes: Epinephelidae) and related commercial species applying multiplex PCR. Neotrop Ichthyol 14 (3): e150128. DOI: $10.1590 / 1982-0224-20150128$

Carvalho DC, Oliveira DA, Pompeu PS, Leal CG, Oliveira C, Hanner R. 2011. Deep barcode divergence in Brazilian freshwater fishes: the case of the São Francisco River basin. Mitochondrial DNA 22 (suppl 1): $80-86$.

Dentinger B, Margaritescu S, Moncalvo J. 2010. Rapid and reliable high-throughput methods of DNA extraction for use in barcoding and molecular systematics of mushrooms. Mol Ecol Resour 10 (4): 628633.

DeSalle R, Amato G. 2004. The expansion of conservation genetics. Nat Rev Genet 5 (9): 702-712.

Dias PJ, Wakefield CB, Fairclough DV, Jackson G, Travers MJ, Snow M. 2016. Real-time PCR validation of visually identified snapper Chrysophrys auratus (Sparidae) eggs. J Fish Biol 88 (2): 811-819.

Dirzo R, Raven PH. 2003. Global state of biodiversity and loss. Ann Rev Environ Resour 28 (1): 137-167.

Doi H, Takahara T, Minamoto T, Matsuhashi S, Uchii K, Yamanaka H 2015. Droplet digital polymerase chain reaction (PCR) outperforms real-time PCR in the detection of environmental DNA from an invasive fish species. Environ Sci Technol 49 (9): 5601-5608.

Ekrem T, Willassen E, Stur E. 2007. A comprehensive DNA sequence library is essential for identification with DNA barcodes. Mol Phylogenet Evol 43 (2): 530-542.

Erpenbeck D, Hooper, JNA, Worheide G. 2006. CO1 phylogenies in diploblasts and the 'Barcoding of Life'-are we sequencing a suboptimal partition? Mol Ecol Notes 6: 550-553.

Eytan RI, Hellberg ME. 2010. Nuclear and mitochondrial sequence data reveal and conceal different demographic histories and population genetic processes in Caribbean reef fishes. Evolution 64 (12): 3380 3397.

Faith DP, Williams KJ. 2005. How large-scale DNA barcoding programs can boost biodiversity conservation planning: linking phylogenetic diversity (PD) analyses to the Barcode of Life Database (BOLD). In Australian Entomological Society's 36th AGM and Scientific Conference/7th Invertebrate Biodiversity and Conservation Conference/Australian Systematics Society. Canberra, Australia. December 2005

Feng J, Wu Z, Xie X, Dai Z, Liu S. A real-time polymerase chain reaction method for the identification of four commercially important salmon and trout species. Mitochondrial DNA Part A 28 (1): 104-111.

Ficetola GF, Miaud C, Pompanon F, Taberlet P. 2008. Species detection using environmental DNA from water samples. Biol Lett 4 (4): 423 425 .

Francis CM, Borisenk AV, Ivanova NV, Eger JL, Lim BK, GuillenServent A, Kruskop SV, Mackie I, Hebert PDN. 2010. The role of DNA barcode in understanding and conservation of mammal diversity in southeast Asia. PLoS One 5 (9). DOI: 10.1371/journal.pone.0012575.
Frank DN. 2009. BARCRAWL and BARTAB: software tools for the design and implementation of barcoded primers for highly multiplexed DNA sequencing. BMC Bioinform 10: 362. DOI: 10.1186/1471-2105-10-362

Fredslund J, Schauser L, Madsen LH, Sandal N, Stougaard J. 2005. PriFi: using a multiple alignment of related sequences to find primers for amplification of homologs. Nucleic Acids Res 33 (suppl 2): W516W520.

Freshwater DW, Tudor K, O'shaughnessy K, Wysor B. 2010. DNA barcoding in the red algal order Gelidiales: Comparison of COI with $\mathrm{rbcL}$ and verification of the "barcoding gap". Cryptogam Algol 31 (4): 435.

Goldstein PZ, DeSalle R. 2011. Integrating DNA barcode data and taxonomic practice: determination, discovery, and description. Bioessays 33 (2): 135-147.

Gómez F. 2014. Problematic biases in the availability of molecular markers in protists: The example of the dinoflagellates. Acta Protozool 53 (1): 63.

Group CPW, Hollingsworth PM, Forrest LL, Spouge JL, Hajibabaei M, Ratnasingham S, van der Bank M, Chase MW, Cowan RS, Erickson DL, Fazekas AJ. 2009. A DNA barcode for land plants. Proceedings of the National Academy of Sciences 106 (31): 12794-12797.

Hajibabaei M, Janzen DH, Burns JM, Hallwachs W, Hebert PD. 2006. DNA barcodes distinguish species of tropical Lepidoptera. Proceedings of the National Academy of Sciences of the United States of America 103 (4): 968-971.

Hamaguchi M, Manabe M, Kajihara N, Shimabukuro H, Yamada Y, Nishi E. 2017. DNA barcoding of flat oyster species reveals the presence of Ostrea stentina Payraudeau, 1826 (Bivalvia: Ostreidae) in Japan. Mar Biodivers Rec 10 (1): 4.

Handy SM, Chizhikov V, Yakes BJ, Paul SZ, Deeds JR, Mossoba MM. 2014. Microarray chip development using infrared imaging for the identification of catfish species. Appl Spectroscopy 68 (12): 13651373

Handy SM, Mueller S, Jacob SM, Paul SZ, Garrett SD, Deeds JR. 2016. Evaluation of the Agilent Technologies Bioanalyzer-based DNA Fish Identification Solution. Food Control 73: 627(7). DOI: 10.1016/ j.foodcont.2016.09.013

Hawlitschek O, Nagy ZT, Berger J, Glaw F. 2013. Reliable DNA barcoding performance proved for species and island populations of comoran squamate reptiles. PloS One 8 (9): e73368. DOI: 10.1371/journal.pone. 0073368

Hebert PD, Ratnasingham S, de Waard JR. 2003. Barcoding animal life: cytochrome c oxidase subunit 1 divergences among closely related species. Proceedings of the Royal Society of London B: Biological Sciences 270 (Suppl 1): S96-S99.

Hebert PD, Stoeckle MY, Zemlak TS, Francis CM. 2004. Identification of birds through DNA barcodes. PLoS Biol 2 (10): e312. DOI: 10.1371/journal.pbio.0020312.

Hebert PD, Zakharov, EV, Prosser SW, Sones JE, McKeown JT, Mantle B, La Salle, J. 2013. A DNA 'Barcode Blitz': Rapid digitization and sequencing of a natural history collection. PLoS One 8 (7): e68535. DOI: 10.1371/journal.pone.0068535.

Hebert PDN, Cywinska A, Ball SL, de Waard JR. 2003. Biological identifications through DNA barcodes. Proc R Soc London Ser B Biol Sci 270: 313-321.

Hemery LG, Eléaume M, Roussel V, Améziane N, Gallut C, Steinke D, Cruaud C, Couloux A, Wilson NG. 2012. Comprehensive sampling reveals circumpolarity and sympatry in seven mitochondrial lineages of the Southern Ocean crinoid species Promachocrinus kerguelensis (Echinodermata). Mol Ecol 21 (10): 2502-2518.

Higashi R, Sakuma K, Chiba SN, Suzuki N, Chow S, Semba Y, Okamoto H, Nohara K. 2016. Species and lineage identification for yellowfin Thunnus albacares and bigeye $T$. obesus tunas using two independent multiplex PCR assays. Fish Sci 82 (6): 897-904.

Hubert N, Hanner R, Holm E, Mandrak NE, Taylor E, Burridge M, Watkinson D, Dumont P, Curry A, Bentzen P, Zhang J. 2008. Identifying Canadian freshwater fishes through DNA barcodes. PLoS One 3 (6): e2490. DOI: 10.1371/journal.pone.0002490.

Hubert N, Meyer CP, Bruggemann HJ, Guerin F, Komeno RJ, Espiau B, Causse R, Williams JT, Planes S. 2012. Cryptic diversity in IndoPacific coral-reef fishes revealed by DNA-barcoding provides new support to the centre-of-overlap hypothesis. PLoS One 7 (3): e28987. DOI: 10.1371/journal.pone.0028987. 
Hutchings JA, Swain DP, Rowe S, Eddington JD, Puvanendran V, Brown JA. 2007. Genetic variation in life-history reaction norms in a marine fish. Proc R Soc London Ser B Biol Sci 274 (1619): 1693-1699.

Ivanova NV, Zemlak TS, Hanner RH, Hebert PD. 2007. Universal primer cocktails for fish DNA barcoding. Mol Ecol Notes 7 (4): 544-548.

Iwatsuki Y, Tanaka F, Allen GR. 2015. Lutjanus xanthopinnis, a new species of snapper (Pisces: Lutjanidae) from the Indo-west Pacific, with a redescription of Lutjanus madras (Valenciennes 1831). J Ocean Sci Found 17: 22-42

Janzen DH, Hallwachs W, Blandin P, Burns JM, Cadiou J, Chacon I, Dapkey T, Deans AR, Epstein ME, Espinoza B, Franclemont JG. 2009. Integration of DNA barcoding into an ongoing inventory of complex tropical biodiversity. Mol Ecol Res 9 (s1): 1-26.

Katoh K, Standley DM. 2013. MAFFT multiple sequence alignment software version 7: improvements in performance and usability. Mo Biol Evol 30 (4): 772-780.

Keele JA, Carmon J L, Hosler DM. 2013. Polymerase chain reaction: Preparation and analysis of raw water samples for the detection of dreissenid mussels. Technical Memorandum No. 86-68220-13-13.

Kerr KC, Stoeckle MY, Dove CJ, Weigt LA, Francis CM, Hebert PD. 2007. Comprehensive DNA barcode coverage of North American birds. Mol Ecol Notes 7 (4): 535-543.

Keskİn E, Atar HH. 2013. DNA barcoding commercially important fish species of Turkey. Mol Ecol Res 13 (5): 788-797.

Khedkar GD, Jamdade R, Naik S, David L, Haymer D. 2014. DNA barcodes for the fishes of the Narmada, one of India's longest rivers. PLoS One 9 (7): e101460. DOI: 10.1371/journal.pone.0101460

Kiewnick S, Holterman M, van den Elsen S, van Megen H, Frey JE, Helder J. 2014. Comparison of two short DNA barcoding loci (COI and COII) and two longer ribosomal DNA genes (SSU \& LSU rRNA) for specimen identification among quarantine root-knot nematodes (Meloidogyne spp.) and their close relatives. Eur J Plant Pathol 140 (1): 97-110.

Ko HL, Wang YT, Chiu TS, Lee MA, Leu MY, Chang KZ, Chen, WY, Shao KT. 2013. Evaluating the accuracy of morphological identification of larval fishes by applying DNA barcoding. PLoS One 8 (1): e53451. DOI: 10.1371/journal.pone.053451.

Kochzius M, Seidel C, Antoniou A, Botla S K, Campo D, Cariani A, Vazquez EG, Hauschild J, Hervet C, Hjörleifsdottir S, Hreggvidsson G. 2010. Identifying fishes through DNA barcodes and microarrays. PLoS One 5 (9): e12620. DOI: 10.1371/journal.pone.0012620.

Krishnamurthy PK, Francis RA. 2012. A critical review on the utility of DNA barcoding in biodiversity conservation. Biodivers Conserv 21 (8): 1901-1919.

Kwok S, White TJ, Taylor JW. 1986. Evolutionary relationships between fungi, red algae, and other simple eucaryotes inferred from total DNA hybridizations to a cloned basidiomycete ribosomal DNA. Exp Mycol 10 (3): 196-204.

Lakra WS, Verma MS, Goswami M, Lal KK, Mohindra V, Punia P, Gopalakrishnan A, Singh KV, Ward RD, Hebert P. 2011. DNA barcoding Indian marine fishes. Mol Ecol Res 11 (1): 60-71.

Layton KK, Martel AL, Hebert PD. 2014. Patterns of DNA barcode variation in Canadian marine molluscs. PLoS One 9 (4): e95003. DOI: 10.1371/journal.pone.095003

Li R, Dao Z. 2011. Identification of Meconopsis species by a DNA barcode sequence: The nuclear internal transcribed spacer (ITS) region of ribosomal deoxyribonucleic acid (DNA). Afr J Biotechnol 10 (70): 15805-15807.

Lim H, Abidin MZ, Pulungan CP, de Bruyn M, Nor SAM. 2016. DNA Barcoding Reveals High Cryptic Diversity of the Freshwater Halfbeak Genus Hemirhamphodon from Sundaland. PLoS One 11 (9): e0163596. DOI: 10.1371/journal.pone. 0163596

Little DP, Stevenson DW. 2007. A comparison of algorithms for the identification of specimens using DNA barcodes: examples from gymnosperms. Cladistics 23 (1): 1-21.

Lowenstein JH, Amato G, Kolokotronis SO. 2009. The real maccoyii: identifying tuna sushi with DNA barcodes-contrasting characteristic attributes and genetic distances. PLoS One 4 (11): 7866. DOI: 10.1371/journal.pone.07866.

Mabragaña E, de Astarloa JMD, Hanner R, Zhang J, Castro MG. 2011. DNA barcoding identifies Argentine fishes from marine and brackish waters. PLoS One 6 (12): e28655. DOI: 10.1371/journal.pone.0068535.

Macaya EC, Zuccarello GC. 2010. DNA Barcoding and genetic divergence in the Giant Kelp Macrocystis (Laminariales) 1. J Phycol 46 (4): 736-742.
Martínez-Aquino A, Reyna-Fabián ME, Rosas-Valdez R, Razo-Mendivil U, de León GPP, García-Varela M. 2009. Detecting a complex of cryptic species within Neoechinorhynchus golvani (Acanthocephala: Neoechinorhynchidae) inferred from ITSs and LSU rDNA gene sequences. J Parasitol 95 (5): 1040-1047.

Meier R, Shiyang K, Vaidya G, Ng PK. 2006. DNA barcoding and taxonomy in Diptera: a tale of high intraspecific variability and low identification success. Syst Biol 55 (5): 715-728.

Meier R, Zhang G, Ali F. 2008. The use of mean instead of smallest interspecific distances exaggerates the size of the "barcoding gap" and leads to misidentification. Syst Biol 57 (5): 809-813.

Meyer CP, Paulay G. 2005. DNA barcoding: error rates based on comprehensive sampling. PLoS Biol 3 (12): e422. DOI: 10.1371/journal.pbio.0030422.

Mohammed-Geba K, Mahdy, AA, Eissa, AS, Osman AG. 2016. Analysis of population genetics of the endangered nile pufferfish Tetraodon lineatus (Linnaeus, 1758) in the upper Egyptian River Nile. Intl J Ecotoxicol Ecobiol 1 (2): 60-66.

Mora C, Tittensor DP, Adl, S, Simpson AG, Worm B. 2011. How many species are there on Earth and in the ocean?. PLoS Biol 9 (8): e1001127. DOI: 10.1371/journal.pbio.1001127.

Moulton MJ, Song H, Whiting MF. 2010. Assessing the effects of primer specificity on eliminating numt coamplification in DNA barcoding: a case study from Orthoptera (Arthropoda: Insecta). Mol Ecol Resour 10 (4): 615-627.

Naaum AM, Hanner R. 2015. Community engagement in seafood identification using DNA barcoding reveals market substitution in Canadian seafood. DNA Barcodes 3 (1): 74-79.

Nagy ZT, Sonet G, Glaw F, Vences M. 2012. First large-scale DNA barcoding assessment of reptiles in the biodiversity hotspot of Madagascar, based on newly designed COI primers. PLoS One 7 (3): e34506. DOI: 10.1371/journal.pone.0034506

Naim DM, Rosly HAAM, Mohd SA. 2012. Assessment of Phylogenetic Inter-Relationships in Mud Crab Genus Scylla (Portunidae) Based on Mitochondrial DNA Sequence. INTECH Open Access Publisher, Croatia.

Neigel J, Domingo A, Stake J. 2007. DNA barcoding as a tool for coral reef conservation. Coral Reefs 26 (3): 487-499.

Pappalardo AM, Ferrito V. 2015. DNA barcoding species identification unveils mislabeling of processed flatfish products in southern Italy markets. Fish Res 164: 153-158.

Park, DS, Foottit R, Maw E, Hebert PD. 2011. Barcoding bugs: DNAbased identification of the true bugs (Insecta: Hemiptera: Heteroptera). PLoS One 6 (4): e18749. DOI: 10.1371/journal.pone.018749.

Pawlowski J, Audic S, Adl S, Bass D, Belbahri L, Berney C, Bowser SS, Cepicka I, Decelle J, Dunthorn M, Fiore-Donno AM. 2012. CBOL protist working group: barcoding eukaryotic richness beyond the animal, plant, and fungal kingdoms. PLoS Biol 10 (11): e1001419. DOI: 10.1371 /journal.pbio.1001419.

Pereira SL, Baker AJ. 2004. Low number of mitochondrial pseudogenes in the chicken (Gallus gallus) nuclear genome: Implications for molecular inference of population history and phylogenetics. BMC Evol Biol 4: 17. DOI: 10.1186/1471-2148-4-17

Perl RB, Nagy ZT, Sonet G, Glaw F, Wollenberg KC, Vences M. 2014. DNA barcoding Madagascar's amphibian fauna. Amphib-Reptil 35 (2): 197-206.

Pramual P, Adler PH. 2014. DNA barcoding of tropical black flies (Diptera: Simuliidae) of Thailand. Mol Ecol Resour 14 (2): 262-271.

Ratnasingham S, Hebert PDN. 2007. BOLD: the barcode of life data system (www.barcodinglife.org). Mol Ecol Notes 7: 355-364.

Roe AD, Sperling FA. 2007. Patterns of evolution of mitochondrial cytochrome c oxidase I and II DNA and implications for DNA barcoding. Mol Phylogenet Evol 44 (1): 325-345.

Rubinoff D, Cameron S, Will K. 2006. A genomic perspective on the shortcomings of mitochondrial DNA for "barcoding" identification. J Hered 97 (6): 581-594.

Rubinoff D. 2006. Utility of mitochondrial DNA barcodes in species conservation. Conserv Biol 20 (4): 1026-1033.

Saitoh T, Sugita N, Someya S, Iwami Y, Kobayashi S, Kamigaichi H, Higuchi A, Asai S, Yamamoto Y, Nishiumi I. 2015. DNA barcoding reveals 24 distinct lineages as cryptic bird species candidates in and around the Japanese Archipelago. Mol Ecol Res 15 (1): 177-186. 
Saunders GW, Kucera H. 2010. An evaluation of rbcL, tufA, UPA, LSU and ITS as DNA barcode markers for the marine green macroalgae. Cryptogamie. Algol 31 (4): 487-528.

Schmidt S, Schmid-Egger C, Morinière J, Haszprunar G, Hebert PD. 2015. DNA barcoding largely supports 250 years of classica taxonomy: identifications for Central European bees (Hymenoptera, Apoidea partim). Mol Ecol Resour 15 (4): 985-1000.

Schoch CL, Seifert KA, Huhndorf S, Robert V, Spouge JL, Levesque CA Chen W, Bolchacova E, Voigt K, Crous PW, Miller AN. 2012. Nuclear ribosomal internal transcribed spacer (ITS) region as a universal DNA barcode marker for Fungi. Proc Natl Acad Sci USA 109 (16): 6241-6246

Shao'e Sun QL, Kong L, Yu H, Zheng X, Yu R, Dai L, Sun Y, Chen J, Liu J, Ni L, Feng Y. 2016. DNA barcoding reveal patterns of species diversity among North Western Pacific molluscs. Nature Sci Rep 6: 33367. DOI: $10.1038 / \mathrm{srep} 33367$

Shen Y, Guan L, Wang D, Gan X. 2016. DNA barcoding and evaluation of genetic diversity in Cyprinidae fish in the midstream of the Yangtze River. Ecol Evol 6 (9): 2702-2713.

Shendure J, Ji H. 2008. Next-generation DNA sequencing. Nature Biotechnol 26 (10): 1135-1145.

Sherwood AR, Presting GG. 2007. Universal Primers Amplify a 23s rDNA Plastid Marker in Eukaryotic Algae and Cyanobacteria1. Phycol 43 (3): 605-608.

Shokralla S, Hellberg RS, Handy SM, King I, Hajibabaei M. 2015. A DNA mini-barcoding system for authentication of processed fish products. Nature Sci Rep 5: 15894. DOI: 10.1038/srep15894

Simberloff D, Martin JL, Genovesi P, Maris V, Wardle DA, Aronson J, Courchamp F, Galil B, García-Berthou E, Pascal M, Pyšek P. 2013 Impacts of biological invasions: what's what and the way forward Trends Ecol Evol 28 (1): 58-66

Smith PJ, McVeagh SM, Steinke D. 2008. DNA barcoding for the identification of smoked fish products. J Fish Biol 72 (2): 464-471.

Song H, Buhay JE, Whiting MF, Crandall KA. 2008. Many species in one: DNA barcoding overestimates the number of species when nuclear mitochondrial pseudo genes are coamplified. Proc Natl Acad Sci USA 105 (36): 13486-13491.

Sriwattanarothai N, Steinke D, Ruenwongsa P, Hanner R, Panijpan B. 2010. Molecular and morphological evidence supports the species status of the Mahachai fighter Betta sp. Mahachai and reveals new species of Betta from Thailand. J Fish Biol 77 (2): 414-424.

Steinke D, Zemlak TS, Boutillier JA, Hebert PD. 2009a. DNA barcoding of Pacific Canada's fishes. Mar Biol 156 (12): 2641-2647.

Steinke D, Zemlak TS, Hebert PD. 2009b. Barcoding Nemo: DNA-based identifications for the ornamental fish trade. PLoS ONE 8 (7) e68535. DOI: 10.1371/journal.pone.0068535

Stockle MY, Hebert PD. 2008. Barcode of life. Sci Am 299 (4): 82-88

Swartz ER, Mwale M, Hanner R. 2008. A role for barcoding in the study of African fish diversity and conservation. South Afr J Sci 104 (7-8): 293-298.

Tamura K, Stecher G, Peterson D, Filipski A, Kumar S. 2013. MEGA6: molecular evolutionary genetics analysis version 6.0. Mol Biol Evol 30 (12): 2725-2729.

Taylor HR, Harris WE. 2012. An emergent science on the brink of irrelevance: a review of the past 8 years of DNA barcoding. Mol Ecol Res 12 (3): 377-388.

Thiriet PD, Di Franco A, Cheminée A, Guidetti P, Bianchimani O, Basthard-Bogain S, Cottalorda JM, Arceo H, Moranta J, Lejeune P, Francour P. 2016. Abundance and diversity of crypto-and nectobenthic coastal fish are higher in marine forests than in structurally less complex macroalgal assemblages. Plos One 11 (10): e164121. DOI: 10.1371/journal.pone.0164121

Trivedi S, Aloufib AA, Ansari AA, Ghosh SK. 2016. Role of DNA barcoding in marine biodiversity assessment and conservation: an update. Saudi J Biol Sci 23 (2): 161-171.
Van Steenkiste N, Locke SA, Castelin M, Marcogliese DJ, Abbott CL. 2015. New primers for DNA barcoding of digeneans and cestodes (Platyhelminthes). Mol Ecol Res 15 (4): 945-952.

Vargas S, Schuster A, Sacher K, Büttner G, Schätzle S, Läuchli B, Hall K, Hooper JN, Erpenbeck D, Wörheide G. 2012. Barcoding sponges: an overview based on comprehensive sampling. PLoS One 7 (7): e39345. DOI: 10.1371/journal.pone.0039345.

Virgilio, M, Backeljau, T, Nevado B, De Meyer M. 2010. Comparative performances of DNA barcoding across insect orders. BMC Bioinform 11: 206. doi: 10.1186/1471-2105-11-206.

Ward RD, Holmes BH, White WT, Last PR. 2008. DNA barcoding Australasian chondrichthyans: results and potential uses in conservation. Mar Freshw Res 59 (1): 57-71.

Ward RD, Holmes BH, White WT, Last PR. 2008. DNA barcoding Australasian chondrichthyans: results and potential uses in conservation. Mar Freshwat Res 59 (1): 57-71.

Ward RD. 2009. DNA barcode divergence among species and genera of birds and fishes. Mol Ecol Res 9 (4): 1077-1085.

Waterton C, Ellis R, Wynne B. 2013. Barcoding nature: shifting cultures of taxonomy in an age of biodiversity loss. Routledge, London.

Weigand AM, Jochum A, Pfenninger M, Steinke D, Klussmann-Kolb A. 2011. A new approach to an old conundrum-DNA barcoding sheds new light on phenotypic plasticity and morphological stasis in microsnails (Gastropoda, Pulmonata, Carychiidae). Mol Ecol Res 11 (2): $255-265$.

Will KW, Rubinoff D. 2004. Myth of the molecule: DNA barcodes for species cannot replace morphology for identification and classification. Cladistics 20 (1): 47-55.

Williams Z, Ben-Dov I. Z, Elias R, Mihailovic A, Brown M, Rosenwaks Z, Tuschl T. 2013. Comprehensive profiling of circulating microRNA via small RNA sequencing of cDNA libraries reveals biomarker potential and limitations. Proceedings of the National Academy of Sciences 110 (11): 4255-4260.

Wilson EO. 2000. Editorial: On the Future of Conservation Biology. Conserv Biol 14 (1): 1-3.

Wong EHK, Hanner RH. 2008. DNA barcoding detects market substitution in North American seafood. Food Res Intl 41 (8): 828837.

Xia Y, Gu HF, Peng R, Chen Q, Zheng YC, Murphy RW, Zeng XM. 2012. COI is better than 16S rRNA for DNA barcoding Asiatic salamanders (Amphibia: Caudata: Hynobiidae). Mol Ecol Res 12 (1): 48-56.

Yan S, Lai G, Li L, Xiao H, Zhao M, Wang M. 2016. DNA barcoding reveals mislabelling of imported fish products in Nansha new port of Guangzhou, Guangdong province, China. Food Chem 202: 116-119.

Yassin A, Markow TA, Narechania A, O'Grady PM, DeSalle R. 2010. The genus Drosophila as a model for testing tree-and character-based methods of species identification using DNA barcoding. Mol Phylogenet Evol 57 (2): 509-517.

Ye J, Coulouris G, Zaretskaya I, Cutcutache I, Rozen S, Madden TL. 2012. Primer-BLAST: a tool to design target-specific primers for polymerase chain reaction. BMC Bioinform 13: 134. DOI: 10.1186/1471-2105-13-134

Zainal Abidin DH, Mustaffa SA, Rahim MM, Nair D, Md Naim D, Mohd Nor SA. 2016. Population genetics of the black scar oyster, Crassostrea iredalei: repercussion of anthropogenic interference. Mitochondrial DNA Part A 27 (1): 647-658

Zhang JB, Hanner R.2011. DNA barcoding is a useful tool for the identification of marine fishes from Japan. Biochem Syst Ecol 39 (1): 31-42.

Zhang T, Shao MF, Ye L. 2012. 454 Pyrosequencing reveals bacterial diversity of activated sludge from 14 sewage treatment plants. ISME J 6 (6): 1137-1147

Zou Y, Ma C, Zhang Y, Du Z, You F, Tan X, Zhang PJ. 2016. Isolation and characterization of Vibrio alginolyticus. from cultured amphioxus Branchiostoma belcheri tsingtauense. Biologia 71 (7): 757-762. 